\title{
Water and Circular Cities
}

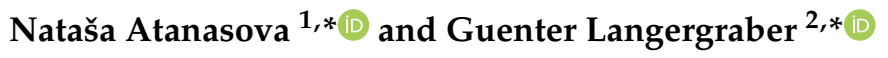 \\ 1 Faculty of Civil and Geodetic Engineering, University of Ljubljana, Jamova 2, 1000 Ljubljana, Slovenia \\ 2 Institute of Sanitary Engineering and Water Pollution Control, Department of Water, Atmosphere and \\ Environment, University of Natural Resources and Life Sciences, Vienna (BOKU), Muthgasse 18, \\ 1190 Vienna, Austria \\ * Correspondence: natasa.atanasova@fgg.uni-lj.si (N.A.); guenter.langergraber@boku.ac.at (G.L.)
}

Citation: Atanasova, N.;

Langergraber, G. Water and Circular Cities. Water 2021, 13, 3585.

https://doi.org/10.3390/w13243585

Received: 6 December 2021

Accepted: 7 December 2021

Published: 14 December 2021

Publisher's Note: MDPI stays neutral with regard to jurisdictional claims in published maps and institutional affiliations.

Copyright: (C) 2021 by the authors. Licensee MDPI, Basel, Switzerland. This article is an open access article distributed under the terms and conditions of the Creative Commons Attribution (CC BY) license (https:// creativecommons.org/licenses/by/ $4.0 /)$.
The Special Issue "Water and Circular Cities" comprises 13 paper and was prepared under the patronage of the COST Action CA17133 Circular City (Implementing naturebased solutions (NBS) for creating a resourceful circular city; https:/ / circular-city.eu/ (accessed on 2 December 2021)). COST (European Cooperation in Science and Technology, www.cost.eu (accessed on 2 December 2021)) is funded through the EU Horizon Programme.

In the core part of the Special Issue, the COST Action Circular City presents its framework for addressing Urban Circularity Challenges (UCCs) with nature-based solutions (NBSs) [1]. The framework comprises a catalogue of technologies for providing/recovering resources with NBS and the analysis of input and output resource streams required for NBS units and interventions. The catalogue comprises a set of 39 NBS units, 12 NBS interventions, and 10 supporting units. The framework was analyzed by experts from various urban sectors, which refer to different fields of activities for circular management of resources in cities. The urban sectors relate to the Action's Working Groups and comprise the built environment [2], urban water management [3], resource recovery [4], and urban farming [5]. In the final paper related to the framework [6], main findings from the sector analyses are presented, different sector perspectives are discussed, and ways to overcome identified differences are shown. Additionally, it is concluded that experts from various disciplines can engage in a cross-sectoral exchange and identify the full potential of NBSs to recover resources in circular cities and provide secondary benefits to improve the livelihood for locals.

Additionally, to evaluate the level of circularity of resources' management in cities, appropriate indicators are proposed by the COST Action and presented in this Special Issue [7]. Other papers included in the Special Issue focus on several aspects of using NBS for creating circular economies in cities, i.e., green roofs and vertical greenery systems [8,9]; production of food in cities [10,11], vacuum toilets generating blackwater [12] as well as biogas plants [13].

We thank all authors for contributing to the Special Issue and thus making it a success.

Last but not least, we thank COST (European Cooperation in Science and Technology; www.cost.eu (accessed on 2 December 2021)) for funding the APC of seven papers [6-10,12,13].

Author Contributions: N.A. and G.L.: Conceptualization, writing-original draft preparation, review and editing. All authors have read and agreed to the published version of the manuscript.

Funding: This Special Issue is based upon work from COST Action CA17133 Circular City, supported by COST (European Cooperation in Science and Technology). www.cost.eu.

Institutional Review Board Statement: Not applicable.

Informed Consent Statement: Not applicable.

Conflicts of Interest: The authors declare no conflict of interest. 


\section{References}

1. Langergraber, G.; Castellar, J.A.C.; Pucher, B.; Baganz, G.F.M.; Milosevic, D.; Andreucci, M.B.; Kearney, K.; Pineda-Martos, R.; Atanasova, N. A Framework for Addressing Circularity Challenges in Cities with Nature-based Solutions. Water 2021, $13,2355$. [CrossRef]

2. Pearlmutter, D.; Pucher, B.; Calheiros, C.S.C.; Hoffmann, K.A.; Aicher, A.; Pinho, P.; Stracqualursi, A.; Korolova, A.; Pobric, A.; Galvão, A.; et al. Closing water cycles in the built environment through nature-based solutions: The contribution of vertical greening systems and green roofs. Water 2021, 13, 2165. [CrossRef]

3. Oral, H.V.; Radinja, M.; Rizzo, A.; Kearney, K.; Andersen, T.R.; Krzeminski, P.; Buttiglieri, G.; Cinar, D.A.; Comas, J.; Gajewska, M.; et al. Management of urban waters with nature-based solutions in circular cities. Water 2021, 13, 3334. [CrossRef]

4. Van Hullebusch, E.D.; Zeeman, G.; Kisser, J.; Vaccari, M.; Di Lonardo, S.; van Eekert, M.; Griessler Bulc, T.; Bani, A.; Melita, S.; Istenič, D.; et al. Nature-based units as building blocks for resource recovery systems in cities. Water 2021, 13, 3153. [CrossRef]

5. Canet-Martí, A.; Pineda-Martos, R.; Junge, R.; Bohn, K.; Paço, T.A.; Delgado, C.; Alencikiene, G.; Skar, S.L.G.; Baganz, G.F.M. Nature-based Solutions for Agriculture in Circular Cities: Challenges, Gaps and Opportunities. Water 2021, 13, 2565. [CrossRef]

6. Langergraber, G.; Castellar, J.A.C.; Andersen, T.R.; Andreucci, M.B.; Baganz, G.F.M.; Buttiglieri, G.; Canet-Martí, A.; Carvalho, P.N.; Finger, D.C.; Griessler Bulc, T.; et al. Towards a cross-sectoral view on nature-based solutions for enabling circular cities. Water 2021, 13, 2352. [CrossRef]

7. Nika, C.-E.; Expósito, A.; Kisser, J.; Bertino, G.; Oral, H.V.; Dehghanian, K.; Vasilaki, V.; Iacovidou, E.; Fatone, F.; Atanasova, N.; et al. Validating Circular Performance Indicators: The interface between Circular Economy and Stakeholders. Water 2021, 13, 2198. [CrossRef]

8. Prenner, F.; Pucher, B.; Zluwa, I.; Pitha, U.; Langergraber, G. Rainwater use for Vertical Greenery Systems: Development of a conceptual model for a better understanding of the processes and influencing factors. Water 2021, 13, 1860. [CrossRef]

9. Hachoumi, I.; Pucher, B.; DeVito-Francesco, E.; Prenner, F.; Ertl, T.; Langergraber, G.; Fürhacker, M.; Allabashi, R. Impact of green roofs and vertical greenery systems on surface runoff quality. Water 2021, 13, 2609. [CrossRef]

10. Baganz, G.F.M.; Schrenk, M.; Körner, O.; Baganz, D.; Keesman, K.J.; Goddek, S.; Siscan, Z.; Baganz, E.; Doernberg, A.; Monsees, H.; et al. Causal Relations of Upscaled Urban Aquaponics and the Food-Water-Energy Nexus-A Berlin Case Study. Water 2021, 13, 2029. [CrossRef]

11. Mino, E.; Pueyo-Ros, J.; Škerjanec, M.; Castellar, J.A.; Viljoen, A.; Istenič, D.; Atanasova, N.; Bohn, K.; Comas, J. Tools for edible cities: A review of tools for planning and assessing edible nature-based solutions. Water 2021, 13, 2366. [CrossRef]

12. Todt, D.; Bisschops, I.; Chatzopoulos, P.; van Eekert, M.H.A. Practical performance and user acceptance of novel dual-flush vacuum toilets. Water 2021, 13, 2228. [CrossRef]

13. Llano, T.; Dosal, E.; Lindorfer, J.; Finger, D.C. Application of multi-criteria decision-making tools for assessing biogas plants: A case study in Reykjavik, Iceland. Water 2021, 13, 2150. [CrossRef] 